\title{
George Coolbul: imagining a colonised life
}

\author{
Malcolm Allbrook
}

The lives of George Coolbul and Henry Prinsep intersected briefly during the six years between 1866 and 1872, when Prinsep employed Coolbul as a stockman on his properties near Bunbury, 140 kilometres south of Perth. We know a great deal about Prinsep, a prominent citizen of the colony and a prolific artist who, between 1898 and 1907, was Western Australia's first Chief Protector of Aborigines and in this position the chief architect of the notorious Aborigines Act 1905. The Battye Library of Western Australian History holds a large collection of Prinsep's papers: diaries covering his colonial life from his arrival from England aged 22 in 1866 until his death in Busselton in 1922, letters from his wide circle of family and friends in England, other colonial posts and Western Australia, reminiscences and memoirs and over 1,000 photographs, sketches and drawings.

Of Coolbul, by contrast, we know virtually nothing and what we do know is through the eyes of Prinsep in his various guises as pastoral employer, church-going humanitarian and artist. Their period of interaction was well before the systematic collection of intrusive government information - initiated by Prinsep and perfected by his successor AO Neville who, over his long tenure as Chief Protector (1915-1940), instituted a system of record keeping that brought almost every Indigenous person in Western Australia into a panopticon of government surveillance, their relationships documented, their movements and most personal details catalogued, commented upon and evaluated.

Aboriginal people of Coolbul's era largely escaped this obsessive documentation, but as a consequence have almost disappeared from the historical record, along with their responses, resistance and accommodation, the way they lived, worked and died. Given Prinsep's later role in establishing the legislative regime that laid the foundations for administrative intrusion into Aboriginal lives, it is a little perverse that he has become Coolbul's unwitting biographer. Yet his imperfect and culturally-blinkered record provides a framework from which to imagine a colonised life and identify strategies Coolbul adopted as he tried to function within a new regime while trying to maintain a measure of pre-colonial independence for himself and his family.

I came across Coolbul while reading the diaries of Henry Prinsep as part of my doctoral research into his life as a member of a large and widely dispersed imperial family. ${ }^{1}$ During Prinsep's first few years in Australia, Coolbul, together with another Aboriginal man, Charlie Neeribun, and some other Nyungahs, ${ }^{2}$ feature regularly in Prinsep's ultimately unsuccessful endeavours to turn around the fortunes of his Cal- 
cutta-based father's Western Australian properties by supplying timber and horses to Indian markets. ${ }^{3}$ Later I viewed the small bound collection of five pencil and crayon drawings by Coolbul held by the Art Gallery of Western Australia. These drawings, selected and bound by Prinsep into a volume entitled Western Australian native art, are visually startling, full of life and movement. ${ }^{4}$ Four of the five drawings show aspects of life on the properties, various animals and white people on horseback. A blue horse (Figure 3.1) drawn on lined paper is a fine study of the animal frozen in the act of pacing. Coolbul has captured a moment in the movement of the animal, its head slightly thrust forward, ears and eyes, tail and legs providing the impression of fluid movement. Other studies of horses in motion are featured in two smaller drawings displayed on facing pages of the album (Figure 3.2). The top drawing, which appears to have been cut from a larger page and glued into the album, shows a white man, in hunting attire carrying a whip. It is drawn in red, white and blue. The impression is of speed and harmony between rider and animal. The horse's plaited mane, its ears and tail and the rider's plumes fly out in the wind. The rider is perfectly mounted in the saddle, controlling the movement of the swift animal through softly held reins. In the lower drawing, the horse trots nobly, with a white woman in side saddle superimposed over the horse's image. Coolbul has drawn the woman's clothing in detail. She wears a long riding habit, with a high buttoned bodice, plumed riding hat and goggles, her hair braided and wound into a mat at the back. The woman resembles Prinsep's drawings and photographs of his young wife Josephine (nee Bussell), by all accounts an excellent rider who looked 'divine on a horse'. ${ }^{5}$ Coolbul's drawing of a red kangaroo and blue hunting dogs (Figure 3.3) is another vivid depiction of movement displaying the final moments of a scene that the artist must have witnessed many times. The figure of the kangaroo, small compared with the pursuing dogs, is in silhouette, while the two dogs close in, their sharp teeth bared, ears laid back, on the point of making their kill. The final drawing (Figure 3.4) on a large folded page is quite different from the others. Here, four horses and an unmounted white rider are gathered around what appears to be a fenced yard which encloses two trees. The finely drawn horses are all in silhouette, unsaddled and unbridled, either walking or standing. The rider, in red jacket, white side-buttoned riding breeches, boots, spurs and helmet and holding a long stick, is unmounted, perhaps thrown from one of the horses. The rough wood fencing is viewed as if from

1. Allbrook 2008.

2. Contemporary south-western Aboriginal peoples identify and refer to themselves as Nyungahs, a convention followed in this essay. Within the culturally contiguous southwestern block, a number of inter-related language groups have been identified by various non-Aboriginal ethnographers and linguists over the period of colonisation, although the terminologies vary considerably. Following Thieberger 1993, the language group of the south-western coastal area from Bunbury to Augusta is Wardandi, the coast and hinterland from around Bunbury north to around Mandurah is Binjarub, and the Swan River area Wajuk.

3. His father, Charles Prinsep, held the post of Advocate General in the East India Company until his retirement to England in 1854. While in India Prinsep senior invested heavily in Singapore, Van Dieman's Land and Western Australia. From 1838 he steadily added to his Western Australian holdings, which eventually covered 23,500 acres. He did all this without visiting the colony.

4. Coolbul, 'West Australian native art, 1868-1869: book of pencil and crayon sketches'.

5. Brockman, 'Reminiscences, 1872-1956'. 
above, laid out flat around a space blocked in blue crayon, from which the two trees with their weeping boughs protrude. The meaning of the drawing is unclear. There is no scale or compass orientation, no discernible top or bottom, right or left, suggesting that it was drawn while flat on the ground, with the artist adding features as he rotated the page or moved around it.

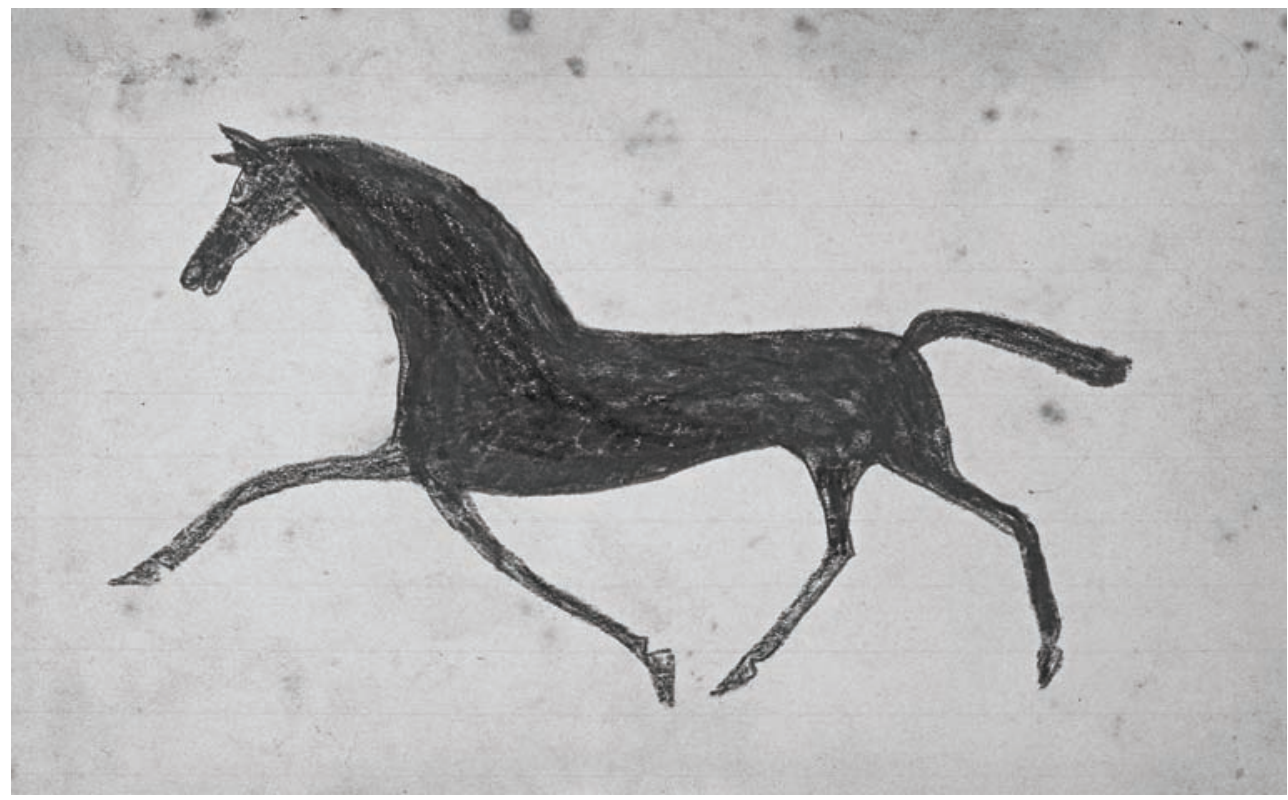

Figure 3.1 (above) and Figure 3.2 (below).

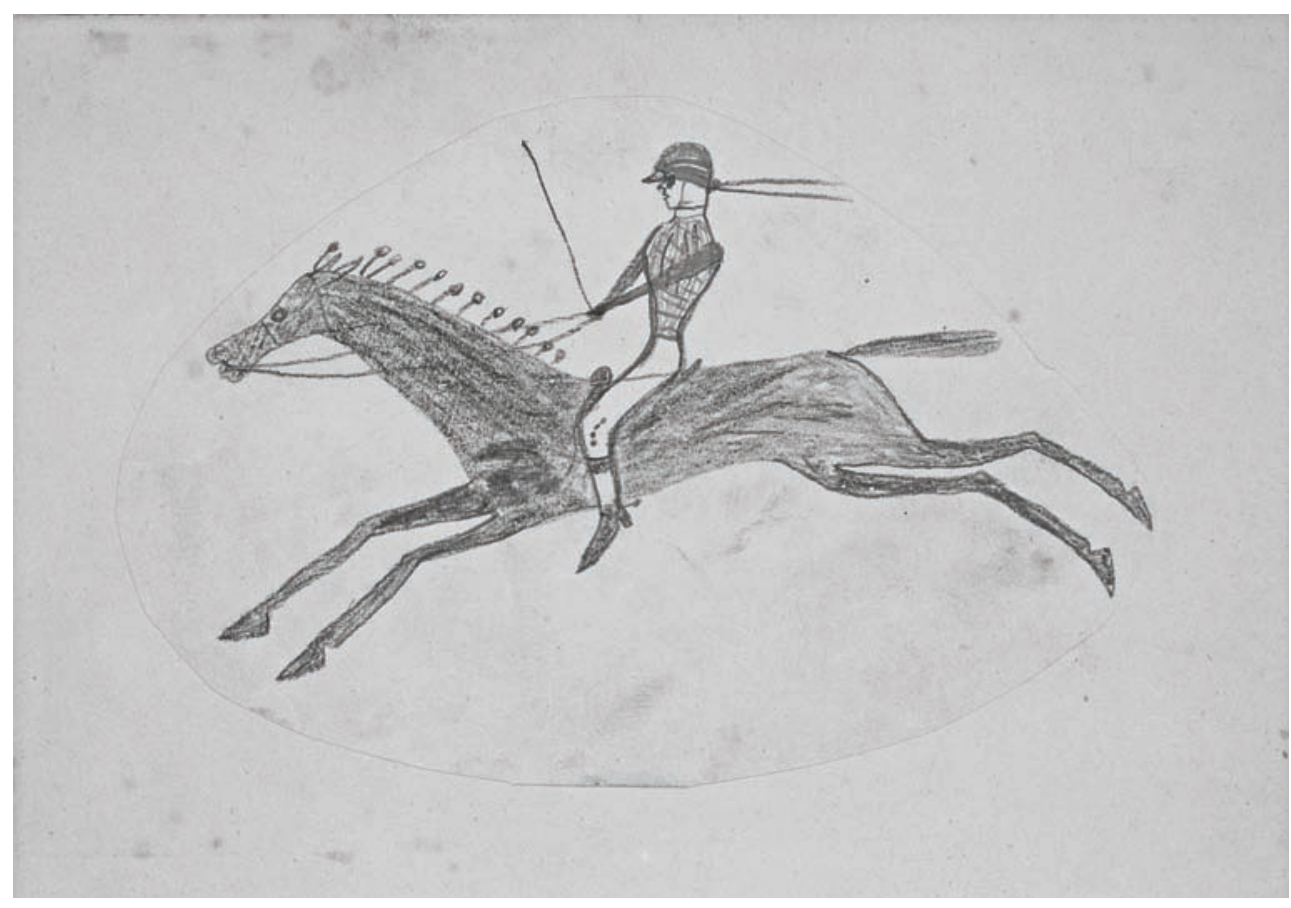




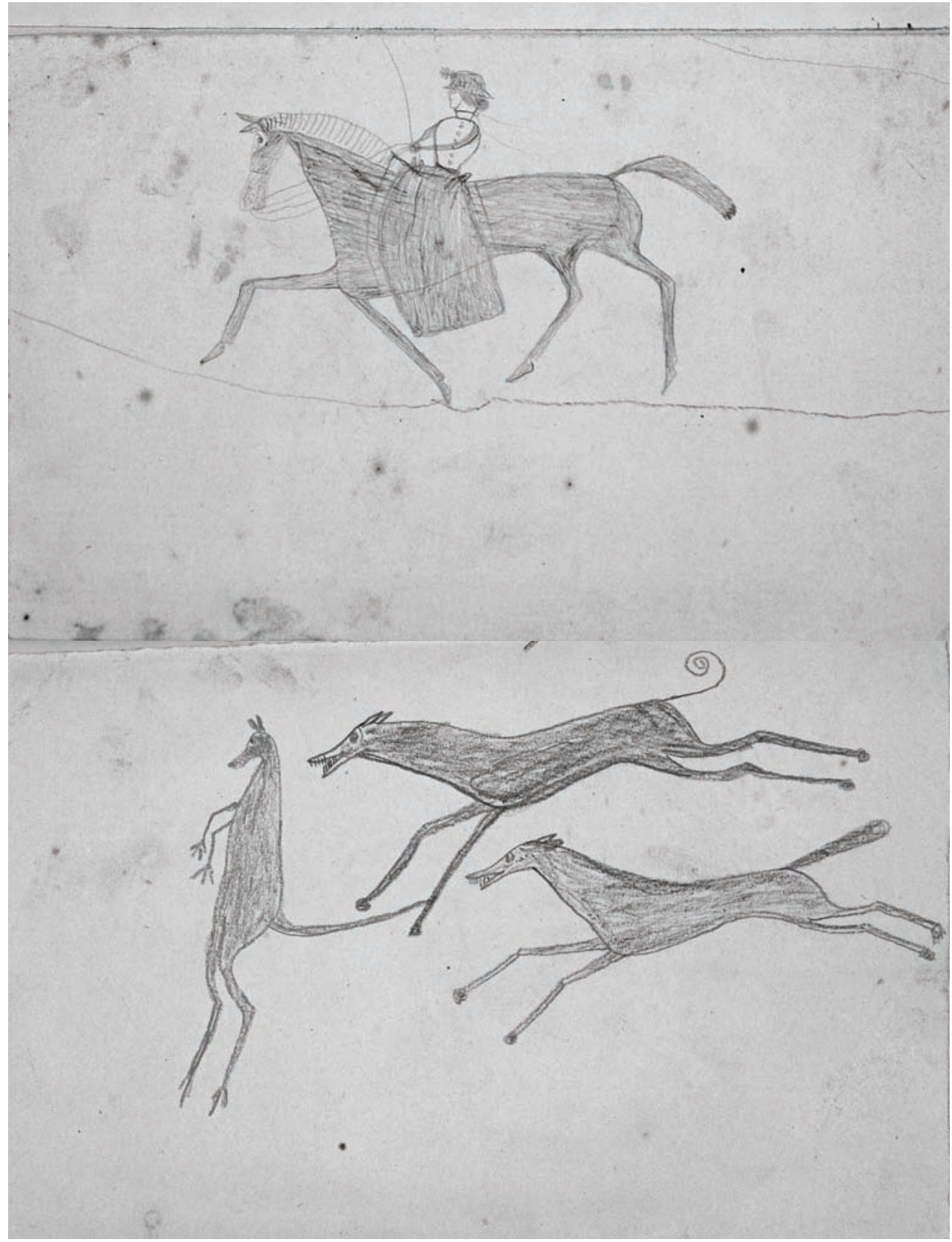

Figure 3.3. 




Figure 3.4.

Prinsep's brief foreword to the volume gives little information about Coolbul or the context in which the drawings were produced. He tells us only that:

The drawings in this book are few among many drawn by a West Australian native known as George Coolbul, of the Vasse district during his service with me on a horse station at Prinsep Park, Dardanup in 1868 and 1869. He came to an untimely end in 1871 being speared through the body by another native during a feast which prevented his further progress in art. ${ }^{6}$ 
Prinsep provides no indication of Coolbul's artistic motivations. There is nothing in the drawings to explain what Coolbul was seeking to convey: none of the interpretive notations by the white patrons of Native American 'ledger book' artists, nor of the 'artistic and ethnographic collaboration' between Billingee and Daisy Bates in early 20th-century Broome. ${ }^{7}$ Unlike the 19th-century Aboriginal artists William Barak and Tommy McRae, he did not sell his work to colonisers. ${ }^{8}$ Coolbul's art was not known or appreciated by a white audience (beyond Prinsep himself) at the time of its production. Beyond the obvious conclusions that he was strongly influenced by the colonial context in which he lived and worked and that he made use of introduced forms and materials, the meaning of Coolbul's art remains inaccessible. The inability to illuminate the meanings of Coolbul's work, as well as the likelihood that what remains represents but a tiny sample of his total output, suggests that his drawings should be 'under-interpreted', as Andrew Sayers advocates, 'in acknowledgement of the impossibility of ... selecting a meaning from a range of possible and often divergent meanings that might be attached to any of them'. 9 Instead they should be viewed, as Howard Morphy proposes, as 'sources of historical understanding and as works of art in their own right'. ${ }^{10}$

From Prinsep we learn that Coolbul was a man 'of the Vasse' and thus probably a member of the language group known as Wardandi, whose country stretched from Bunbury along the coast and hinterland as far as present day Augusta. ${ }^{11}$ As the Swan River Colony expanded southwards from 1839 and as the Bussell and Molloy families spread out northward from their original holdings at Augusta in 1830, his country was encroached. Wardandi country was certainly appealing to the colonisers, being fertile and well-watered, with a temperate climate and well-tended by its traditional owners, as Lieutenant HW Bunbury found when he rode through the area in 1839 and large numbers of men followed him through this country. Bunbury also found abundant game and fish, lush vegetation and a maze of native tracks. Colonisation of the area ensued rapidly after Bunbury's visit, so that by the end of the 1840s farms covered much of the coastal strip between Perth and the nascent settlements at Bunbury and Busselton.

Early colonial policies towards Indigenous peoples were characterised by ambiguity, seeking simultaneously to protect Aboriginal people under the British rule of law while guaranteeing the imposed proprietary rights of the colonisers. ${ }^{12}$ The attitudes of humanitarian colonisers such as John Garrett Bussell, a man of the church who became Prinsep's father-in-law in 1869, epitomise these contradictions. On the one hand he advocated policies of non-violence and benevolence towards the region's Aboriginal people but, on the other, he saw them as unpredictable, unknowable and in need of a firm colonial hand to guide them from a state of savagery to civilisation. 'They are here at present very peaceful', Bussell wrote in 1831, 'and yet there is something that makes one shudder when he crosses unawares in his path the naked Lord of the Forest ${ }^{\prime}{ }^{13}$ Early

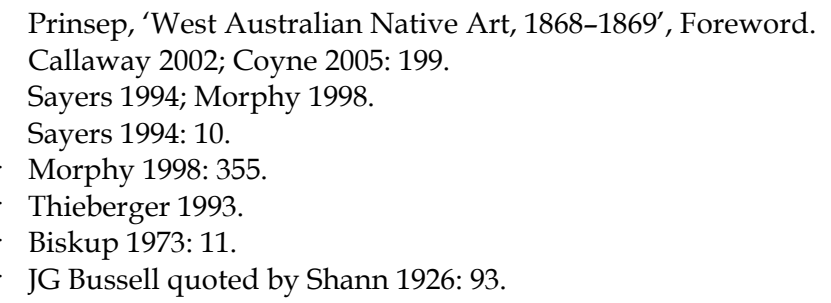


relationships between the family and the traditional owners were fraught and anxious, with John's sister Bessie reporting how in 1837 ' the natives really completely beset us':

They nearly drive me out of my mind. I am obliged to stand around and watch them, and when I am able to return to my lawful labours I find myself thoroughly tired. To me now it seems sacrilege to breathe the name of native in an hour of rest, it is so fraught with fatigue, fear and anxiety. ${ }^{14}$

Family members responded with increasing violence to the expectations of the traditional owners that they share their food and resources, threatening to shoot a woman believed to have stolen salt-cellars to make spear tips, and holding a child hostage against the return of flour allegedly stolen by her father in $1834 .{ }^{15}$ Charles Bussell, in particular, was strident in his condemnation of a Swan River colonial government that he thought was preoccupied 'with the natives' interests' over those of the colonisers, expressing a widely held view that its military action at Pinjarra in 1834 against the Murray River Nyungahs had been 'properly severe' and made them 'peaceful and even useful to the European'. ${ }^{16}$ In June 1837, nine Aboriginal people were killed at Busselton by a party, which included Lenox Bussell, in retaliation for the spearing of their servant Dawson in the arm. Bessie wrote that she feared 'more women were killed than men' and that later her brothers 'Vernon and Alfred went down to the estuary, and saw that the natives had been afraid to return and bury their dead. So they left their cows and came home for spades to perform this last office for them. They threw in the dirt and laid the sods carefully over like an English grave. ${ }^{17}$ The violence continued in 1840, when John Garrett Bussell put aside his humanitarian leanings to participate in a posse to avenge the death of George Layman, a settler at Wonnerup near Busselton. At least seven Nyungahs died 'in the confusion', and an unknown number of others were wounded. ${ }^{18}$

The Rev John Wollaston, who arrived to establish his parish at Picton near Bunbury in 1841, appeared to accept prevailing European views that there was little chance the Nyungah population would ever reconcile themselves to the loss of their lands and domination by a new regime, agreeing that it was 'not beneficial' to 'encourage them about the premises, unless they are employed. They are of too rude a nature to bear it'. ${ }^{19}$ He supported the efforts of colonial officials, such as Protector of Natives Charles Symonns and local Constable Edward Hester, to use the threat of removal to the prison on Rottnest Island to control the Nyungar population and the removal of children from the 'baneful influences of heathen customs', and from 'the evil example of the white people of the common sort', so that they could be educated at the cost of settler families, who might then employ them as domestic servants. ${ }^{20}$ By 1846, the combination of introduced illnesses, such as influenza and venereal disease, and violence had effectively decimated the Indigenous population, who thereafter were not considered a

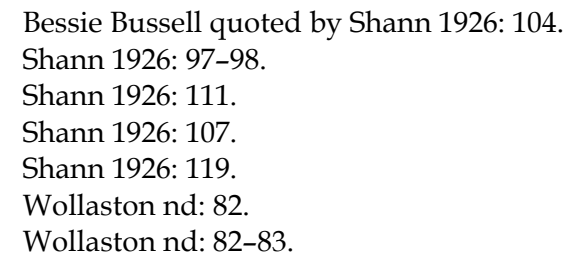


threat to the colonising project. Many years later, Prinsep's daughter Carlotta was able to sanitise her family's early relationships with local Aboriginal people by ascribing the violence that had occurred to the moral debasement of the traditional owners and the intemperate actions of a few lower class whites. Colonisation, she believed, had proceeded smoothly and brought 'very little trouble ... except when my grandfather [JG Bussell] was away for a time, when there was some trouble from the blacks learning how good the white man's food was, would often steal it'. She added that:

It must have been a great temptation to them after the life they had been accustomed to, a sort of 'hand to mouth' existence. There was trouble at Wonnerup when Mr. Layman was killed, but that was his own fault, because he pulled a blackfellow's beard, a terrible insult. ${ }^{21}$

This then was the context in which Coolbul lived his life. Born probably around the time white people first came to the region, he was likely to have directly experienced the violence of contact, observed the way his old people responded to the threats of colonisation and witnessed the transformation of his lands and his people's way of life. By the time Prinsep arrived in 1866, Coolbul had been working on the stations for some years, along with a number of other country men and women such as Timbal, whom Prinsep would later encounter in later life in his role as Chief Protector, 'Kitty', a young woman employed in the house, and Tommy Cattle, who later was the main informant for colonist Jesse Hammond's book on Aboriginal people, Winjan's People. ${ }^{22}$ The day after his arrival, Prinsep met his station workforce of ' 5 English, 1 Hindu and 2 native Australians, Coolbool (George) \& an object called Nooky'. He described the Aboriginal workers as 'funny fellows, who would always burst their boilers as it were with two big shouts of laughter for the first 3 days or so that I knew them', which Prinsep took to be 'their way of showing bashfulness to a stranger'. ${ }^{23}$

Coolbul and Charlie Neeribun figure prominently in Prinsep's management of the station and through them he became aware of other Aboriginal people, who lived nearby in the hills to the east of the properties and outside the colonial economy. Sometimes he would hear 'howling and screaming a mile \& a half away through bush'. ${ }^{24}$ The homestead was visited by families coming in from the bush for meetings nearby, allowing Prinsep to observe their dancing and use of the 'kyle or boomerang ${ }^{25}{ }^{2}$ On one level, he found them a source of entertainment and sustenance: he learned to throw the boomerang and they supplied the homestead with wild game. Prinsep attempted to learn Nyungah words, writing up a 'short list of aboriginal words' for clothing, livestock, water and food, an activity that suggested curiosity or the need to acquire a language of command. ${ }^{26}$ Soon after his arrival, Prinsep bought new work clothes for Coolbul and Neeribun, commenting that Neeribun looked 'a great swell in his new shirt, boots \& trousers ... instead of his dirty kangaroo skin' ${ }^{27}$ Despite their importance to the station

\footnotetext{
21. Brockman, 'Reminiscences, $1872-1956$ ', no page numbers.

22. These people are identified by WB Mitchell, who managed the Prinsep properties before Henry's arrival, in his wages book.

23. Prinsep, 'Diaries', 3 June 1866.

24. Prinsep, 'Diaries', 22 September 1866.

25. Prinsep, 'Diaries', 8 June 1866.

26. Prinsep, 'List of aboriginal native words'.

27. Prinsep, 'Diaries', 15 June 1866.
} 
economy as hunters, horse-breakers and stockmen, they were paid less for their work than European labourers: Prinsep's budget for 1870 allocated $£ 60$ for a stockman, £36 for a 'native [station] man', and $£ 25$ for a 'native helper' ${ }^{28}$ Labour was a chronic problem for Prinsep, and he regularly remarked on the poor attitudes and 'surliness' of the European men in his employ. Coolbul and Neeribun too caused him problems - they would be absent without his permission for long periods or in trouble for drunkenness and fighting. Prinsep tried to show he was boss with mixed success. In May 1869 Prinsep recorded that 'Neeribun appeared at sundown inebriated \& got more troublesome, until I had to eject him forcibly'. ${ }^{29}$ Some months later, 'I had to use my fists at the native huts and scatter them as they were fighting and squalling'. ${ }^{30}$ This was not long after he noted that:

Coolbool was troublesome in the evening \& I was hiding for him and chasing him with a stockwhip all about the fields. He called out for his spears but the other blackfellows knew too well not to give them to him. It was fine fun in the moonlight but he was too wary and swift tho' I very nearly had him once or twice. ${ }^{31}$

Prinsep's diaries show little appreciation of the circumstances of the Indigenous people nearly 40 years after the colonisers' arrival, but they do hint at the complexity of relationships on the stations. They focus on Coolbul and Neeribun as workers, while their kin are framed as exotic, mystifying but often troublesome presences in the landscape. ${ }^{32}$ In sharp contrast to his detailed accounts of the Europeans in the area, there is little obvious curiosity in Prinsep's account about the Nyungah people around him. The words or views of Coolbul and his kin are rarely recorded: they are simply 'funny fellows', valuable but erratic and troublesome workers. He was familiar with some of the Nyungah kin networks, naming many individuals in his diary, but their presence was incidental; they were simply there, a people without a history and devoid of family and cultural context, in Pratt's words, a 'speechless, denuded, biologized body'. ${ }^{33}$

Nonetheless, from the records of Prinsep and other members of his family, a far more nuanced image of the circumstances of the Nyungah populations emerges than one that characterises them solely in the depths of colonial disease and despondency. Men like Coolbul and Neeribun and their families were attached through employment to local farmers and so were closely associated with the colonisers. As well as working for the white man, they appear to have mediated contact between the settlers and those of their kin who remained outside the white sphere. It is clear that family groups gathered regularly on Prinsep's properties for ceremonies, meetings and sometimes burials. $^{34}$ Similarly, individuals often came to the homestead to visit Coolbul and Neeribun. Carlotta Prinsep later recalled how on the visits of one such man, Burman,

\footnotetext{
Prinsep, 'Diaries', 28 October 1869.

Prinsep, 'Diaries', 30 May 1869.

Prinsep, 'Diaries', 21 August 1869.

Prinsep, 'Diaries', 21 July 1869.

Pratt 1992: 6.

Pratt 1992: 53.

34. Prinsep records, for example, in October 1866 his observations of 'old doctor's grave' near the homestead, a 'thatched hut with a small paling around it, inside of which was a set fire, ready for his ghost to light if it felt cold, some spears \& a wommera or throwing stick \& in front of all to the west his grave'.
} 
she would sit with him on the grassy banks of the river and share the sweet, freshly cooked fish:

Burman so black with bundle of long spears, his 'cooter bage' made of possum skin \& his large cloak ... made of Kangaroo skins neatly sewn together with a bone needle \& kangaroo tail sinews. His head bound tightly with a wide band of string made from the fur of the possum skins all rolled together into one long string \& well greased \& rubbed with 'Wilghi', a sort of paint ... composed of grease coloured with ochre, charcoal, ashes or pipe-clay. ${ }^{35}$

Apart from employed men like Coolbul and Neeribun and unattached ones like Burman, other groups of Aboriginal people filled Carlotta's childhood on the family stations. A large and mostly unidentified group of 'natives' lived in camps, worked every now and again as farm workers but were often noisy, drunk and unruly and lived in squalid circumstances. These were people who rarely worked for the farmers, but were provided with basic rations by the white families and moved around the region. Carlotta remembered such people as 'nuisances', always demanding food, quarrelling, 'shouting \& screaming that used to frighten the children'. ${ }^{36}$ A smaller group of known and named people had been with the Prinseps since early childhood and had sometimes been raised 'almost as one of the family'. Some of them continued to live near the homestead as adults, providing general labour for the family in return for some pay and keep. According to another family memoir recorded by John Milward, many local settler families had close relationships with Aboriginal people, who were 'adopted' as children and grew up as companions for the settler children. ${ }^{37} \mathrm{He}$ was, however, obviously sensitive about such relationships and wrote that they were 'very hard for the younger generation to understand'. But he insists they were based on mutual respect. The Nyungahs were not 'servile slaves', but were respected as men, stockmen and equals and in turn gave respect 'without any sense of inferiority'. At the same time, he writes of 'short, sharp' punishments, of treatment as 'naughty and unreliable children', and conveys an obvious sense that Nyungah workers were, despite being portrayed as 'members of the family', expected to submit without question to the authority of their patrons. ${ }^{38}$

By the 1870s relationships between the district's ever-growing settler population and the now largely dispossessed traditional landowners had come to be based on the harsh benevolence of what Mary Anne Jebb has called 'pastoral paternalism', a 'complex dynamic between violence and protection ... which was an enduring characteristic of station culture and life with a white Boss' in which those who had survived the initial onslaughts of colonisation and remained in their country had 'learned the rules of occupation' and 'found a place that assured their survival' ${ }^{39}$ Prinsep's account suggests that even with increasing white domination of their world, it was still possible for Nyungahs to move around their traditional country and escape, if only for a short time, the growing constraints on their movement.

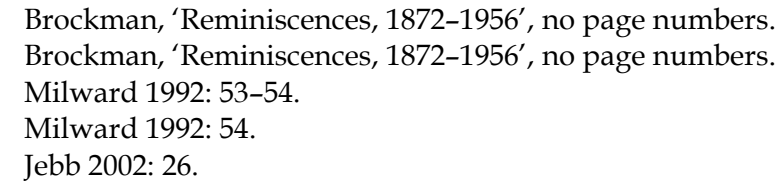


Coolbul's drawings suggest an additional dimension to the relationship between black and white that does not occur in Prinsep's diaries. While we cannot be certain of his motivations, Coolbul's acute observations of animals and European ways do suggest an interest in things that were unfamiliar and perhaps unfathomable to him and his kin. In all likelihood it was his interactions with Prinsep the artist that kindled his interest in drawing, an interest Prinsep encouraged by supplying him with paper, pencils and crayons. Prinsep spent much time at his easel and derived enormous pleasure from painting and drawing, and it is certain that Coolbul would have had plenty of opportunity to observe the way his boss went about his art and the results of his work. We can speculate that Coolbul's interest in art might have been a way of engaging Prinsep's interest, of exploring other dimensions to the employer-employee relationship. A shared interest in art might have been a way of developing understanding, exchanging values and encouraging respect from a boss who displayed little obvious interest in anything Aboriginal people had to offer. It is also possible, as Morphy speculates, that Coolbul's art represented a way of bringing the unfamiliar world of the coloniser into an Aboriginal frame of reference, 'of incorporating them within Aboriginal ways of understanding the world and making them a part of an Aboriginal universe' ${ }^{40}$ Still another possibility comes from Brenda Croft's observation that Coolbul's kangaroo and dogs may symbolise the colonial relationship, in which 'the native fauna under attack operate as the symbol for the Indigenous observer: already out of the picture' ${ }^{41}$

The fact that Coolbul's drawings are but a small sample of the artist's total output, however, suggests that they tell us as much about Henry Prinsep as about Coolbul. Because the subjects of the drawings are all European, it is intriguing to imagine what might have been discarded in Prinsep's final selection, to wonder whether, like William Barak or Tommy McRae, Coolbul might have drawn images of his Nyungah country men and women going about their traditional business or scenes depicting the violent history of his people's subjugation by the colonisers. The reasons these particular drawings were included in the album are open to speculation, but do suggest an assimilationist interest: that the drawings were seen by Prinsep as curiosities, as examples of what someone like Coolbul could achieve when exposed to the 'civilising' influence of colonisation. It is even possible that Prinsep selected these drawings because they were trivial or sentimental: that the man and woman on horseback were Prinsep and his wife, while the blue horse might be a drawing for a child, perhaps the baby Carlotta, who, as we have seen, spent much of her childhood with Aboriginal men and women around the homestead. Conjectures like these lead to the uncomfortable conclusion that, as Morphy suggests in his discussion of the art of Albert Namatjira, the Coolbul collection might constitute 'as much as a denial of Aboriginal art as a recognition of $\mathrm{it}^{\prime} .{ }^{42}$

The disjuncture between Prinsep's treatment of Coolbul as worker and Coolbul as artist becomes particularly apparent in his dispassionate reporting of the artist's death. There was, he recorded in March 1872, 'a great row amongst the natives' camped near the homestead.

40. Morphy 1998: 62-63.

41. Croft 2002: 39.

42. Morphy 1998: 22. 
Bejine came up to accuse Neeribun of spearing Geo. Coolbul through the belly, but Charlie denied it. However I took Charlie's nag ... \& rode down to the camps at [illeg.] where I found poor George very bad, the spear had gone right through him to the left of the navel. The women were lamenting \& nursing him. ... I sent Bejine with a letter to P. Clifton asking him to send [Doctor] Lovegrove \& a policeman. When I returned I found Mr. Charlie [Neeribun] had decamped. I was glad of this because he had served us for many years formerly \& I should not like to have been instrumental to his conviction which would only have been founded on native assertions. Poor George I think will not recover tho' James Maguire says he has known similar cases before with sorcery [sic]. Lovegrove and [Police Constable] Slack came out at about 1.30 \& we went to examine George, who was in great pain. Decided to send him into Bunbury. Lovegrove bandaged and washed him \& gave him some Dovers powders to ease his pain \& then we returned to dinner ... Mack went up to put George in the cart \& just as Lovegrove was leaving Mack returned saying George was dead. Lovegrove \& I rode down to see the body \& met a large number of about 20 natives armed with spears \& painted going in search of Charlie. I told them not to spear him but to bring him bound to Bunbury or tell the police. We found poor Kitty, George's pretty wife in a great agony of grief \& about 4 other women singing their dirges over his body. We told them not to bury him until [Resident Magistrate] Mr. Pearce Clifton has seen him tomorrow morning. 43

Prinsep, a Justice of the Peace, attended the inquest the next day and was keen to protect his worker Neeribun from conviction. Witnesses testified that he had speared Coolbul, but this was dismissed as 'founded on native assertions'. The inquest exonerated Neeribun, finding that Coolbul 'met with death from spear wound inflicted by person or persons unknown. There was no material evidence to show Charlie had done it, tho' we all thought so'. ${ }^{44}$ Two days later, a huge storm brought down a tree at the back of homestead, and it landed 'where George and Kitty generally lay'. Later, Prinsep came across 'a lot of natives, strange tribe, on the road in the moonlight \& expected to hear something about Charlie'. Finally in April 1872:

We were disturbed by Burman \& Gippy, two native relatives of Coolbul, who was killed. They were in great agitation from mingled grief \& wine, \& swore Charlie's death which I strenuously warned them against. Burman ... mentioned having noticed some words flying along the telegraph wire about George's death, to Fremantle where he was, \& when he went to the office, sure, the words were written down exactly the same. ${ }^{45}$

Thus Coolbul died like so many of his country men and women un-mourned by a colonial system that seemed to regret only the passing of a valued if troublesome worker. Prinsep lived on until 1922 and is remembered for his art, his public service and contribution to the social and cultural life of colonial Western Australia. On his death he was eulogised as 'an old colonist', 'one of the State's oldest and best known residents', 'always polite, always courteous, always kind and wishing to be helpful', 'a Christian gentleman of the old school' ${ }^{46}$ By this time, Coolbul's traditional country was

43. Prinsep, 'Diaries', 7 March 1872.

44. Prinsep, 'Diaries', 8 March 1872.

45. Prinsep, 'Diaries', 7 March 1872.

46. The West Australian, 21 July 1922; West Australian Church News, 1 August 1922. 
covered by farms, the Nyungah families shut out of their traditional economy, relegated to the status of pauper and, in Haebich's words, 'branded as social outcasts as well' ${ }^{47}$ Prinsep himself played no small part in this decline in status and respect in his later role as Chief Protector of Aborigines, designing and advocating laws which today lead many West Australian Aboriginal people to rank him second to AO Neville on the scale of 'devils incarnate' responsible for their oppression.

The story of men like George Coolbul, concealed as it is behind the words and images of the coloniser, shows that Nyungahs did not simply succumb to the steady erosion of their society. Coolbul and his compatriots consciously adopted strategies to resist the increasingly intrusive colonial regime and survive as a people by absenting themselves from the demands of the boss to maintain cultural and family obligations, by making their society invisible to the new regime, by showing their lack of respect for a boss who viewed them as lesser beings and by coming onto their country and using it against the demands of the coloniser. Thus, another story arises from the bleakness of colonisation and the Aborigines Act of 1905, another story that speaks of survival, cultural strength, regeneration and the determination of individual Nyungahs to resist a hated system that interfered with almost every element of their lives. Their resistance, as Nyungah authors Kim Scott and Hazel Brown write, took many forms: it 'was trying to avoid conquest ... adapting different strategies to maintain certain values as others fell away. Resistance was merely surviving, and in such circumstances there must have been a lot of slippage, a lot of compromise and shifting ground.' 48

\section{References}

\section{Primary sources}

Brockman, Carlotta, 'Reminiscences of Carlotta Louisa Brockman, nee Prinsep, 1882-1956', AN931A (Microform), Battye Library, Perth.

Coolbul, George, 'West Australian Native Art, 1868-1869: Book of Pencil and Crayon Sketches', State Art Collection, Art Gallery of Western Australia, Perth.

Milward, John 1992, 'Pioneers of the Warren', MS, personal collection.

Mitchell, WB, 'Wages Book for Prinsep Park and Belvidere', MN 773, AN 3592A/88, Battye Library.

Prinsep, Henry C, ‘Diaries 1866 - 1922', MN 773 AN 499A (Microform), Battye Library, Perth.

— 'List of Aboriginal Native Words', MN 773 AN 3592A/73, Battye Library, Perth.

Newspapers:

The West Australian

West Australian Church News

\section{Secondary sources}

Allbrook, Malcolm 2008, "“Imperial Family”: The Prinseps, Empire and Colonial Government in India and Australia', PhD thesis, Griffith University.

47. Haebich 1988: 46.

48. Scott and Brown 2005: 85. 
Biskup, Peter 1973, Not Slaves, Not Citizens: The Aboriginal Problem in Western Australia, 1898-1954, University of Queensland Press, St. Lucia.

Callaway, Anita 2002, 'Balancing the books: Indigenous autobiography and ledgerbook art' in Rosamund Dalziell (ed), Selves Crossing Cultures: Autobiography and Globalisation, Australian Scholarly Publishing, Melbourne.

Croft, Brenda L 2002, 'Albert's gift' in the Conference Proceedings of the Fourth National Aboriginal and Torres Strait Islander Visual Arts Conference, June 2002, Australia Council for the Arts and Aboriginal and Torres Strait Islander Commission: 28-45.

Coyne, Cynthia 2005, 'Bye and bye when all the natives have gone', in A Cole, V Haskins, and F Paisley (eds), Uncommon Ground: White Women in Aboriginal History, Aboriginal Studies Press, Canberra: 199-213.

Haebich, Anna 1988, For Their Own Good: Aborigines and Government in the Southwest of Western Australia, 1900-1940, University of Western Australia Press, Nedlands.

Jebb, Mary Anne 2002, Blood, Sweat and Welfare: A History of White Bosses and Aboriginal Pastoral Workers, University of Western Australia Press, Nedlands.

Morphy, Howard 1998, Aboriginal Art, Phaidon Press, London and New York.

'Oscar's Sketchbook', National Museum of Australia, viewed on-line, 12 July 2008 : <www.nma.gov.au/interactives/oscar/oscar_online.html>

Pratt, Mary Louise 1992, Imperial Eyes: Travel Writing and Transculturation, Routledge, New York.

Sayers, Andrew 1994, Aboriginal Artists of the Nineteenth Century, Oxford University Press, Melbourne.

Scott, Kim and Hazel Brown 2005, Kayang \& Me, Fremantle Arts Centre Press, Fremantle.

Shann, EOG 1926, Cattle Chosen: The Story of the First Group Settlement in Western Australia, 1829-1841, Oxford University Press, London.

Thieberger, Nicholas 1993, Handbook of Aboriginal Languages South of the Kimberley Region, Department of Linguistics, Research School of Pacific Studies, Australian National University, Canberra.

Wollaston, Rev John Ramsden nd, Wollaston's Picton Journal (1841-1844), Being Volume I of the Journals and Diaries (1841-1856), collected by Rev Canon A Burton, Paterson Brokensha, Perth. 